\title{
ENDOCRINE AND METABOLIC PROFILE IN HOLSTEIN AND RED HOLSTEIN HEIFERS DURING PERIPARTAL PERIOD
}

\author{
KASAGIĆ D*, RADOJIČIĆ BILJANA**, GVOZDIĆ D**, MIRILOVIĆ $M^{* *}$ and MATARUGIĆ $D^{\star * *}$ \\ *Veterinary Institut Republic of Srpska "Dr Vaso Butozan" Banja Luka, Bosnia and Herzegovina \\ **Uversity of Belgrade, Faculty of Veterinary Medicine, Serbia \\ ***Faculty of Agryculture, Banja Luka, Republic of Srpska, Bosnia and Herzegovina
}

\section{(Received 25 ${ }^{\text {th }}$ May 2011)}

The aim of this stady was to examine the relationship between triiodothyronine $\left(T_{3}\right)$, thyroxin $\left(T_{4}\right)$, insulin-like growth factor-I (IGF-I) and blood serum liver function biomarkers concentrations in Holstein and Red Holstein heifers during the peripartal period. In the first experimental group (I) were heifers of Holstein Friesian breed $(n=10)$, and in the second experimental group (II) were Red Holstein heifers $(n=10)$. Blood samples were taken from the vena coccygea three times during the short peripartal period (5 days before delivery, at delivery and 5 days after delivery), and blood serum samples were separated after spontaneous coagulation. Blood serum $T_{3}, T_{4}$ and IGF-I concentrations were determinated using radioimmunoassay (RIA). Blood serum concentrations of glucose (G), total protein (TP), albumin, (Alb), urea, total bilirubin (tBil) and aspartate aminotrasferase (AST) were determined using commercial ELISA kits. The statistical significance between means was determined using Student $t$-test.

Blood serum $T_{3}$ concentration in Group II was significantly lower after delivery, and T4 concentration was significantly higher before delivery $(p<0.05)$, compared to Group I. Mean blood serum IGF-I concentrations between the two experimental groups were not significantly different at all time intervals. Relationships between the determined hormones showed a median positive correlation between $T_{3}$, and $T_{4}(r=0.74)$ in Group I and highly positive correlation in Group II $(r=0.81)$. Blood serum thyroid gland hormones and IGF-I concentrations in healthy heifers during peripartal period vary considerably, the lowest values being determined immediately after calving in both experimental groups.

Blood serum G, TP, Alb and urea concentrations were significantly higher in Group I at all investigated time intervals. Blood serum tBil concentration was significantly higher after partus in Group I (11.02 \pm 3.33 : $8.49 \pm 3.35 \mu \mathrm{mol} / \mathrm{L}$, Group I vs. II, respectively), and AST activity was not significantly different at all intervals.

Key words: Holstein heifers, endocrine and metabolic profile, peripartal period 


\section{INTRODUCTION}

The most significant changes of physiological nature in dairy cows occur during the period of 3 weeks before and after calving, so-called "transition period" (Grummer, 1995). Those changes start during the dry period, exacerbate in the calving period and continue at the beginning of lactation. They represent an adaptation process of dairy cows to increased metabolic demands of the mammary gland. Precisely, the intensification of important metabolic processes and increased energy needs appear during this period, while intake of nutrients is insufficient. The adaptation process is also characterized by the rapid increase of peripheral utilization of different hormones, especially thyroid, pituitary and adrenal glands products. A hormonal status test i.e., dynamics of hormones in charge of regulation of energy metabolism, is significant for further explanation of the relationship between homeostasis and homeoresis in heifers during peripartal period. In the situation of negative energy balance (NEB), the organism uses its own energy stores, first from body fat depot, where their increased mobilization occurs (Holtenius, 1989; Grummer, 1993; Kovačević, 2004). Increased lipid stores mobilization and high energy consumption in the mammary gland usually results in increased blood serum free fatty acids concentration, hypoglycemia and hyperketonemia, the situation that could easily end up as a production disease such as ketosis, fatty liver syndrome or puerperal paresis (Goff and Horst, 1997).

Thyroid gland hormones are important in maintaining lactation and could play a major role in regulating homeoretic adaptation responses. The higher blood serum thyroxin concentration in pregnant heifers with lower production ability suggests a negative relationship of thyroxin to milk yield potential (Bitman et al., 1984). Restricted energy intake could be an important factor in reducing blood serum triiodothyronine concentration during the peripartal period (Pethes et al., 1985). There is also a significant effect of weather conditions on the thyroid gland hormones blood serum levels during different lactation phases (Aceves et al., 1985). Nixon et al. (1988) determined free and total thyroid hormones in the serum of Holstein cows and concluded that free and total $T_{4}$ and $T_{3}$ are low in early lactation due to the high metabolic demands form peak milk production. In his study Tirrats (1997) showed that plasma thyroxin level was significantly lower during early stage of lactation compared with later stages, but increased as the stage of lactation progressed. Stojić et al. (2001) reported that heifers in the early lactation period two to three days after calving had decreased concentrations of $T_{3}$ and $T_{4}$ relative to the days before calving. Positive correlation was established between thyroid hormones in blood and energy balance (Reist et al., 2002).

Insulin-like growth factor (IGF-I) is synthesized in the liver under the influence of somatotropin (STH) (Jones et al., 1995), which is the basics of the STH-IGF-I axis. Early lactation in dairy cows is characterized by prolonged NEB during which the liver becomes insensitive to the STH stimulation (Vicini et al., 1991), leading to a marked reduction of plasma IGF-I concentration. Decrease of IGF-I concentration starts two weeks before parturition, approximately at the time when plasma insulin gradually decreases. At the same time plasma somatotropin level is changing contrary to plasma insulin and IGF-I concentrations (Bell, 1995). 
This situation when STH can not stimulate liver IGF-I synthesis and secretion has been termed "resistance to STH" (Donaghy et al., 1996).

Blood serum total protein, albumin and urea concentrations represent not just indicators of protein metabolism (Kida, 2002), but also liver function biomarkers (Kaneko, 1989). A more specific liver function biomarker in the blood serum is AST activity (Kaneko, 1989; Garry et al., 1994; Rehage et al., 1996; Kida, 2002) and among most commonly used hepatic status indicators is total blood serum bilirubin concentration (Rehage et al., 1996; Kalaitzakis et al., 2007). Blood serum glucose concentration is an energy metabolism indicator, but it can also be used as a liver function biomarker, since hepatic gluconeogenesis is the major contributor to the blood glucose homeostasis in dairy cows (Kida, 2002).

The aim of the present study was to determine blood serum thyroid hormones, IGF-I and liver function biomarkers concentration in two breeds of Holstein heifers during the peripartal period.

\section{MATERIALS AND METHODS}

Experimental animals. Total number of 20 healthy heifers were divided into two experimental groups: 1) the first experimental group (I) were Holstein-Friesian heifers $(n=10)$, and 2) the second experimental group (II) were Red Holstein heifers $(n=10)$. All experimental animals were born and bred on the farm, had normal calving (eutocia) and one live calf (heifers with twins were excluded). The urine ketonic tests have been used (Urocomb stripes and Rother-a test) to exclude the diagnosis of ketosis. The experiment was conducted during the spring time (April-May), with an average environmental temperature between 18$24^{\circ} \mathrm{C}$, and equal diet composition.

Blood sampling. Blood samples were collected three times during the short peripartal period ( 5 days before partus, at the parturation day and 5 days post partum) between 10 and 12 a.m. (about 5 hours after milking and feeding) by vacutainer systems from the vena coccygea (one test tube of blood per sampling, approximately $10 \mathrm{~mL}$ of blood). The blood samples were allowed to clot spontaneously (approximately $15 \mathrm{~min}$ ) at room temperature. The serum was then decanted at $1000 \mathrm{~g}$ and stored at $-18^{\circ} \mathrm{C}$ until analyzed.

Endocrine parameters determination. Thyroid gland hormones $\left(\mathrm{T}_{3}\right.$ and $\left.\mathrm{T}_{4}\right)$ and IGF-I blood serum concentrations were determined by radioimmunoassay (RIA) method, using commercial RIA-kits (INEP, Zemun, Serbia).

Blood serum liver function biomarkers determination. Blood serum glucose (G), total protein (TP), albumin (Alb), urea (BUN), total bilirubin (tBil) and aspartate aminotransferase (AST) activity were determined using commercial ELISA kits (Reanal Finechemical Co.) on biochemical analyser Basic Secoman.

Statistical analysis. Statistical significance of the differences between mean values was determined using Student t-test, and correlation coefficient (r), according to Chebish-ev table, was used for the evaluation of the degree of linear correlation between endocrine parameters. 


\section{RESULTS}

Mean blood serum $\mathrm{T}_{3}$ concentrations for Group I at three time intervals were $2.6 \pm 0.62,2.7 \pm 0.65$ and $2.3 \pm 0.41 \mathrm{nmol} / \mathrm{L}$, and for Group II were 2.49 \pm 0.52 , $2.16 \pm 0.78$ and $1.74 \pm 0.61 \mathrm{nmol} / \mathrm{L}$. Comparing blood serum $\mathrm{T}_{3}$ concentrations within groups, in experimental Group II, a statistically significant difference $(p<0.01)$ was found between the mean at the period after delivery $(1.74 \pm 0.61$ $\mathrm{nmol} / \mathrm{L}$ ) relative to the periods before it. Mean blood serum $\mathrm{T}_{3}$ concentration in Group II after delivery $(1.74 \pm 0.61 \mathrm{nmol} / \mathrm{L})$ was also significantly lower $(p<0.05)$ compared to the mean $\mathrm{T}_{3}$ value in Group I after delivery $(2.3 \pm 0.41 \mathrm{nmol} / \mathrm{L})$.

Mean blood serum $\mathrm{T}_{4}$ concentrations for Group I at three time intervals were $35.70 \pm 9.96,39.70 \pm 12.96$ and $32.2 \pm 7.94 \mathrm{nmol} / \mathrm{L}$, while for Group II were $58.45 \pm 12.86,49.9 \pm 22.42$ and $43.91 \pm 16.89 \mathrm{nmol} / \mathrm{L}$. Mean blood serum $\mathrm{T}_{4}$ concentrations decreased after delivery in both experimental groups, but there were no significant differences between means within groups. Mean blood serum $\mathrm{T}_{4}$ concentration in Group II before delivery $(58.45 \pm 12.86 \mathrm{nmol} / \mathrm{L})$ was significantly higher $(p<0.01)$ compared to the mean $T_{4}$ concentrations at all time intervals in Group I.

Blood serum $T_{3}, T_{4}$ and IGF-I concentrations in Holstein-Friesian (Group I) and Red Holstein heifers (Group II) during the peripartal period are presented in Table 1.

Table 1. Blood serum $T_{3}, T_{4}$ and IGF-I concentrations (mean $\pm S D$ ) in the HolsteinFriesian (Group I) and Red Holstein heifers (Group II) during the peripartal period

\begin{tabular}{|l|l|l|l|l|}
\hline \multirow{2}{*}{ Time of testing } & \multicolumn{1}{|c|}{ Group } & \multicolumn{1}{c|}{$\begin{array}{c}\mathrm{T}_{3} \\
(\mathrm{nmol} / \mathrm{L})\end{array}$} & $\mathrm{T}_{4}(\mathrm{nmol} / \mathrm{L})$ & IGF-I $(\mathrm{nmol} / \mathrm{L})$ \\
\hline \hline \multirow{2}{*}{ Before delivery } & $\mathrm{I}(\mathrm{n}=10)$ & $2.60 \pm 0.62^{\mathrm{NS}}$ & $35.70 \pm 9.96^{\star *}$ & $18.17 \pm 5.17 \mathrm{NS}$ \\
\cline { 2 - 5 } & $\mathrm{II}(\mathrm{n}=10)$ & $2.49 \pm 0.52$ & $58.45 \pm 12.86$ & $18.64 \pm 5.43$ \\
\hline \multirow{2}{*}{ Delivery } & $\mathrm{I}(\mathrm{n}=10)$ & $2.70 \pm 0.65^{\mathrm{NS}}$ & $39.70 \pm 12.96 \mathrm{NS}$ & $19.42 \pm 8.35 \mathrm{NS}$ \\
\cline { 2 - 5 } & $\mathrm{II}(\mathrm{n}=10)$ & $2.16 \pm 0.78$ & $49.90 \pm 22.42$ & $14.15 \pm 3.83$ \\
\hline \multirow{2}{*}{ After delivery } & $\mathrm{I}(\mathrm{n}=10)$ & $2.31 \pm 0.4^{\star}$ & $32.20 \pm 7.94 \mathrm{NS}$ & $12.53 \pm 3.01 \mathrm{NS}$ \\
\cline { 2 - 5 } & $\mathrm{II}(\mathrm{n}=10)$ & $1.74 \pm 0.61$ & $43.91 \pm 16.89$ & $10.46 \pm 3.27$ \\
\hline
\end{tabular}

Legend : NS - not significant; ${ }^{*} p<0.01,{ }^{*} p<0.05$.

Blood serum $\mathrm{T}_{3}, \mathrm{~T}_{4}$ and IGF-I concentrations were lower after delivery compared to the values before it and at parturition in both experimental groups. Statistical analysis of the differences between mean thyroid hormone values in two groups reviled two important facts: 1) mean blood serum $\mathrm{T}_{3}$ concentration after delivery was significantly lower in Group II compared to Group I (1.74 \pm 0.61 : $2.31 \pm 0.41 \mathrm{nmol} / \mathrm{L}, p<0.05)$, and 2) mean blood serum $\mathrm{T}_{4}$ concentration was significantly higher before parturition in Group II compared to Group I. Although there were no significant differences between mean blood serum IGF-I values in two groups of heifers, IGF-I values were lower at parturition and after it in Group II (Red Holstein). 
Acta Veterinaria (Beograd), Vol. 61, No. 5-6, 555-565, 2011.

The degree of correlation between mean blood serum $T_{3}, T_{4}$ and IGF-I concentrations in two breeds of Holstein heifers during the peripartal period is presented in Table 2.

Table 2. The degree of correlation between mean blood serum $T_{3}, T_{4}$ and IGF-I concentrations in two breeds of Holstein heifers during the peripartal period

\begin{tabular}{|c|c|c|c|c|c|c|c|c|c|}
\hline \multicolumn{5}{|c|}{ Group I } & \multicolumn{5}{c|}{ Group II } \\
\hline \hline & & $\mathrm{T}_{3}$ & $\mathrm{~T}_{4}$ & IGF-I & & & $\mathrm{T}_{3}$ & $\mathrm{~T}_{4}$ & IGF-I \\
\hline $\mathrm{T}_{3}$ & $\mathrm{r}$ & - & $0.745^{\star}$ & 0.120 & $\mathrm{~T}_{3}$ & $\mathrm{r}$ & - & $0.812^{\star}$ & 0.402 \\
\hline $\mathrm{T}_{4}$ & $\mathrm{r}$ & $0.745^{\star}$ & - & 0.139 & $\mathrm{~T}_{4}$ & $\mathrm{r}$ & $0.812^{\star}$ & - & 0.148 \\
\hline IGF-I & $\mathrm{r}$ & 0.120 & 0.139 & - & IGF-I & $\mathrm{r}$ & 0.402 & 0.148 & - \\
\hline
\end{tabular}

There was a positive correlation between mean blood serum $T_{3}$ and $T_{4}$ concentrations in Group I ( $r=0.74)$ and high positive correlation ( $r=0.81)$ in Group II. There was a low degree of correlation between IGF-I and thyroid hormone concentrations in both groups of heifers.

Results of blood serum liver function biomarkers are presented in Table 3.

Table 3. Blood serum concentrations of G, TP, Alb, Urea, tBil and AST activity (mean $\pm \mathrm{SD}$ ) in two breeds of Holstein heifers during the peripartal period

\begin{tabular}{|c|c|c|c|c|c|c|c|}
\hline $\begin{array}{l}\text { Time of } \\
\text { testing }\end{array}$ & Group & $\begin{array}{c}\mathrm{G} \\
\text { (mmolLI) }\end{array}$ & $\begin{array}{c}\text { TP } \\
\text { (gLI) }\end{array}$ & $\begin{array}{l}\text { Alb } \\
\text { (g/L) }\end{array}$ & $\begin{array}{c}\text { Urea } \\
(\mathrm{mmol} / \mathrm{L})\end{array}$ & $\begin{array}{c}\text { tBil } \\
(\mu \mathrm{mol} / \mathrm{L})\end{array}$ & $\begin{array}{l}\text { AST } \\
(\mathrm{U} / \mathrm{L})\end{array}$ \\
\hline \multirow{2}{*}{$\begin{array}{l}\text { Before } \\
\text { delivery }\end{array}$} & I $(n=10)$ & & & $\begin{array}{l}39.51 \pm \\
3.48^{\star \star}\end{array}$ & $\begin{array}{l}7.72 \pm \\
2.61 *\end{array}$ & & $\begin{array}{l}67.16 \pm \\
22.91 \text { NS }\end{array}$ \\
\hline & II $(n=10)$ & & $\begin{array}{l}62.81 \pm \\
4.16\end{array}$ & $\begin{array}{l}29.20 \pm \\
4.96\end{array}$ & & & $\begin{array}{l}70.96 \pm \\
44.78\end{array}$ \\
\hline \multirow{2}{*}{ Delivery } & I $(n=10)$ & $\begin{array}{l}2.25 \pm \\
1.38 \text { NS }\end{array}$ & $\begin{array}{l}78.80 \pm \\
6.16^{\star \star}\end{array}$ & $\begin{array}{l}37.32 \pm \\
6.77^{* *}\end{array}$ & & & $\begin{array}{l}84.45 \pm \\
24.64 \mathrm{NS}\end{array}$ \\
\hline & II $(n=10)$ & $\begin{array}{l}2.82 \pm \\
1.28 \\
\end{array}$ & $\begin{array}{l}57.20 \pm \\
9.83\end{array}$ & $\begin{array}{l}26.82 \pm \\
6.45 \\
\end{array}$ & $\begin{array}{l}4.98 \pm \\
1.33 \\
\end{array}$ & $\begin{array}{l}7.89 \pm \\
2.60 \\
\end{array}$ & $\begin{array}{l}91.66 \pm \\
68.15 \\
\end{array}$ \\
\hline \multirow{2}{*}{$\begin{array}{l}\text { After } \\
\text { delivery }\end{array}$} & I $(n=10)$ & $\begin{array}{l}2.78 \pm \\
1.46 \mathrm{NS} \\
\end{array}$ & $\begin{array}{l}78.69 \pm \\
6.30 * \star\end{array}$ & $\begin{array}{l}39.08 \pm \\
4.06^{\star *}\end{array}$ & $\begin{array}{l}8.58 \pm \\
2.90^{\star \star}\end{array}$ & $\begin{array}{l}11.02 \pm \\
3.33^{*}\end{array}$ & $\begin{array}{l}78.63 \pm \\
20.28^{N S}\end{array}$ \\
\hline & II $(n=10)$ & $\begin{array}{l}2.76 \pm \\
0.77 \\
\end{array}$ & $\begin{array}{l}64.62 \pm \\
5.77\end{array}$ & $\begin{array}{l}29.09 \pm \\
4.26\end{array}$ & $\begin{array}{l}4.67 \pm \\
0.83\end{array}$ & $\begin{array}{l}8.49 \pm \\
3.35 \\
\end{array}$ & $\begin{array}{l}119.48 \pm \\
105.40\end{array}$ \\
\hline
\end{tabular}

Legend : NS - not significant; ${ }^{* *} p<0.01,{ }^{*} p<.05$

There were no significant differences in the blood serum glucose concentration between groups during the peripartal period. However, data presented in Table 3. indicates two important facts: 1) blood serum glucose concentration in Group I before delivery is lower than the physiological value for dairy cows (2.52-4.16 mmol/L, Kaneko, 1989), 2) there is no decrease in blood serum glucose concentration in heifers after delivery. 
Blood serum total protein and albumin concentrations were significantly higher in Group I at all investigation periods, but they were within the physiological limits. Similar relationship is evident for urea, with highest value determined in Group I at parturition $(9.60 \pm 3.60 \mathrm{mmol} / \mathrm{L})$.

Blood serum tBil values were continously higher in Group I, with a significant difference between means determined after partus (11.02 $\pm 3.33: 8.49 \pm 3.35$, $p<0.05)$. There were no significant differences in blood serum AST activity between groups in all investigation periods. However, blood serum AST activity increased after partus in Group II, with a high degree of individual variation (119.48 $\pm 105.40 \mathrm{U} / \mathrm{L}$, Group II after partus).

\section{DISCUSSION}

Thyroid gland hormones concentration in the heifers' blood serum during the short peripartal period was lowest after calving in both groups, and is in accordance with research results (Đoković, 1998; Kovačević, 2000; Nikolić et al., 2001; Kovačević, 2004).

In experimental Group I, higher mean blood serum $\mathrm{T}_{3}$ concentrations were noticed at all time intervals relative to the concentration of this hormone in Group II, while heifers in Group II had higher concentrations of $\mathrm{T}_{4}$ hormone.

These findings are in accordance with those of Stojić et al. (2001), who reported that heifers in the early lactation period two to three days after calving have decreased concentrations of $T_{3}$ and $T_{4}$ relative to the days before calving. Food, environment and especially temperature influence the concentration of these hormones (McGuire, 1998). However, Grum et al., (1996) stated that $\mathrm{T}_{3}$ and $\mathrm{T}_{4}$ values in the blood decrease in the case of negative energy balance. Adding fat in meals results in the increase of $T_{3}$, while food rich in concentrate has no influence on $T_{3}$, but results in the increase of $T_{4}$. Triiodothyronine and thyroxin concentration in the blood plasma of dairy cows is significantly lower during lactation relative to the period when the milk gland is inactive. However, values of these hormones in the blood are always lower in cows with higher milk production (Blum et al., 1983).

Many authors have confirmed that $T_{3}$ and $T_{4}$ concentration in the blood serum of cows immediately after calving decreases, relative to their concentration in the dry period (Đoković, 1998; Kovačević, 2000; Nikolić et al., 2001). Under normal setting conditions, cows in the early lactation period have significantly lower concentrations of thyroid hormones in the blood plasma (Aceves et al., 1985). They explain this phenomenon with the fact that animals do not get enough energy during the period of parturition, i.e., they are in negative energy balance (Hart et al., 1978; Pethes et al., 1985; Đoković, 1998, Gvozdić et al., 2006). Nikolić et al. $(1997,2001)$ found that during high pregnancy there is an adequate status of thyroid hormones, while at the beginning of lactation a significant decrease of their concentration occurs in one third of the tested cows. In such conditions in cows with high milk production there is an intensive and uncontrollable lipomobilisation, which results in the violation of liver morphology and functional integrity. It eventually leads to "liver fattening", often accompanied by metabolic 
diseases such as ketosis, or in more difficult cases, hepatic coma (Jorritsma, 2003).

Cows with higher milk production during late pregnancy, early lactation and in the second month of lactation have a considerably lower concentration of blood serum thyroid hormones relative to cows with lower milk production (Kovačević, 2004). Thyroid gland hormones in the blood serum of pregnant heifers with different genetic predispositions for milk production (685 kg per lactation) were lower in the morning than in the afternoon in both groups. There was no difference in the concentration of $T_{3}$ between the two groups, while $T_{4}$ in the blood serum of heifers predisposed for lower milk production was considerably higher than in the other group (Bitman et al., 1984).

In our research the intermediate to high positive correlation between $T_{3}$ and $\mathrm{T}_{4}$ concentration in the blood serum of heifers in the peripartal period $(r=0.745$ and $r=0.812$, Group I and II, respectively) was determined, which is in accordance with the studies done by Kunz et al. (1985) and Kovačević (2004).

The results of blood serum IGF-I concentration in heifers during peripartal period in our research are in accordance with the findings of Bishop (1994) and Bugarski (2002), who pointed that cows in the negative energy balance have lowered IGF-I blood serum concentration. Blood serum IGF-I concentration in dairy cattle is stable during the day and does not change significantly even in conditions when animals are hungry, and hormone secretion is distinctly pulsatory (Glyckman, 1987). However, Wathes et al. (2007) suggested that diet has an important influence on the IGF-I level before delivery.

Longer monitoring of blood IGF-I concentration in cows has proved that it is variable depending on the lactation degree. It is lowest at the very beginning of lactation and gradually increases, reaching highest values during the dry period (Sharma et al., 1994; Grum et al., 1996). Lowest blood IGF-I values after calving may be related to the negative energy balance in the beginning of lactation, resulting from the decrease of IGF-I synthesis in the liver, as well as from its active movement from the blood to colostrum, where its value can be increased even up to 20 times relative to its concentration in the blood (Sharma et al., 1994; Hadsell et al., 1993). As IGF-I concentration in the blood is lowest in the early lactation period, when blood growth hormone concentration is highest, the exact role of IGF-I in early lactation is not quite clear; therefore, galactopoietics' significance is attributed to it only in the period of late lactation (Sharma et al., 1994).

Blood serum glucose concentration is an important indicator of energy metabolism and in ruminants over 3 months age it is entirely dependant on the endogenous synthesis from non-carbohydrate sources by hepatic gluconeogenesis (Radojičić, 1995). Requirement for glucose in dairy cows increases considerably during pregnancy and lactation. In the pregnant animal the fetus and uterus utilize glucose as a major source of energy and in lactation large quantities of glucose from the blood are used by the mammary gland for lactose synthesis (Bell, 1995). The reference range values for blood serum glucose concentration in heifers and cows are 2.5-4.16 mmol/L (Kaneko, 1989).

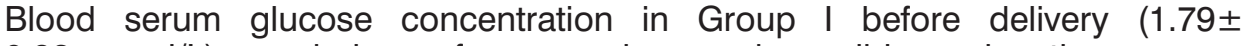
$0.93 \mathrm{mmol} / \mathrm{L})$ was below reference values and possible explanations are as 
follows: 1) low level of highly digestible carbohydrates in the diet, 2) relative decrease of hepatic gluconeogenesis or 3 ) an increase of erythrocytes glucose utilization due to the prolonged blood samples transport time.

Blood serum total protein and albumin concentrations were significantly higher in heifers in Group I in all investigated periods, but the values were within physiological variation interval limits (Kaneko, 1989). A similar relationship is evident for urea concentration, with the highest value determined in Group I at parturition $(9.60 \pm 3.60 \mathrm{mmol} / \mathrm{L})$.

Blood serum tBil values were continously higher in Group I, with a significant difference between means determined after partus (11.02 $\pm 3.33: 8.49 \pm 3.35$, $p<0.05)$. There were no significant differences in blood serum AST activity between groups at all investigated periods. However, blood serum AST activity increased after partus in Group II, with a high degree of individual variation (119.48 $\pm 105.40 \mathrm{U} / \mathrm{L}$, Group II after partus). The blood serum tBil and albumine concentrations, and AST activity are good parameters for the evaluation of liver function status in dairy cows, especially in the peripartal period (Brugere and Brugere, 1987; Radojicic et al., 2007).

Our research results indicate that lower thyroid gland hormones and IGF-I concentration in the blood serum of heifers immediately after calving represent one aspect of organism adaptation to the negative energy balance at the beginning of the first lactation. There is a positive correlation between the degree of negative energy balance and the decrease of the level of thyroid gland hormones. Concentrations of total bilirubin, urea, albumin, and activity of AST are valide liver function biomarkers and good parameters of metabolic status of dairy cows in the first peripartal period.

Address of correspondence

MSc Dragan Kasagic

Veterinary Institute of Republic of Srpska

"Dr Vaso Butozan" Banja Luka

Branka Radičevića 18

78000 Banja Luka

Republic of Srpska

E-mail:kasagicd@veterinarskiinstitutrs.com

\section{REFERENCES}

1. Aceves C, Ruiz A, Romero C, Valverde C, 1985, Homeorhesis during early lactation. Euthyroid sicklike syndrome in lactating cows, Acta Endocrinol (Copenh), 110, 4, 505-9.

2. Bell $A W, 1995$, Regulation of organic nutrient metabolism during transition from late pregnancy to early lactation, J Anim Sci, 73, 2804-19.

3. Bishop DK, Wetteman RP, Spicer LJ, 1994, Body energy reserves influence the onset of luteal activity after early weaning of beef cows, J Animal Sci, 72, 2703-8.

4. Bitman J, Tao H, Akers RM, 1984, Triiodothyronine and thyroxine during gestation in dairy cattle selected for high and low milk production, J Dairy Sci, 67, 11, 2614-9.

5. Blum JW, Kunz P, Leuneberger H, Gautschi K, Keller N, 1983, Thyroid hormones, blood plasma metabolites and haematological parameters in relationship to milk yield in dairy cows, Animal Prod, 36, 39-104. 
6. Brugere-Picoux J, Brugere $H, 1987$, Particularites de la biochemie clinique des ruminants. Rec Vet Med, 163, 11, 1043-53.

7. Bugarski D, 2002, Insulin, IGF-I and liver function parameters concentration in blood of healthy and ketotic cows, Master thesis, University of Belgrade.

8. Chelikani PK, Ambrose DJ, Keisler DH, Kennely JJ, 2009, Effect of dietary energy and protein density on plasma concentrations of leptin and metabolic hormones in dairy heifers, J Dairy Sci, 92, 4, 1430-41.

9. Donaghy AJ, Baxter RC, 1996, Insulin-like growth factor bioactivity and its modification in growth hormone resistant states, Baillieres Clinical Endocrinology and Metabolism, 10, 421-46.

10. Đoković $R, 1998$, Blood lipids, triiodothyronine, thyroxin, insulin and cortisol concentration and liver histology in peripartal cows, $\mathrm{PhD}$ thesis, University of Belgrade.

11. Garry FB, Fettman MJ, Curtis CR, Smith JA, 1994, Serum bile acid concentrations in dairy cattle with hepatic lipidosis, J Vet Internal Med, 8, 432-8.

12. Gluckman PD, Breir BH, Davis SR, 1987, Physiology of the somatotropicaxis with particular reference to the ruminants, J Dairy Sci, 70, 442-6.

13. Grum DE, Drackley JK, Hansen LR, Cremin JD, 1996, Production digestion and hepatic lipid metabolism of dairy cows feed increased energy from fat or concentrate, J Dairy Sci, 79, 183649.

14. Grummer RR, 1995, Impact of changes in organic nutrient metabolism on feeding the transition dairy cow, J Animal Sci, 73, 9, 2820-33.

15. Goff JP, Horst RL, 1997, Physiological changes at parturition and their relationship to metabolic diseases, J Dairy Sci, 80, 1260-8.

16. Gvozdić D, Stojić V, Šamanc H, Đorić G, Vujanac I, 2006, Thyroid gland status and body condition score (BCS) in peripartal dairy cows, Slovenian Vet Res (Suppl), 10, 98-100.

17. Hadsell DL, Baumrucker CR, Kensinger RS, 1993, Effect of elevated blood insuline-like growth factor-I (IGF-I) concentration upon IGF-I in bovine mammary secretions during the colostrum phase, $J$ Endocrinol, 137, 2, 223-30.

18. Hart IC, Bines JA, Roy J, Morant S, 1978, Plasma thyroxine in high and low yieding cattle and calves of different breeds, $J$ Endocrinol, 80, 52-8.

19. Holtenius $P$, 1989, Plasma lipids in normal cows around partus and in cows with metabolic disorders with and without fatty liver, Acta Vet Scand, 30, 4, 441-5.

20. Jones Jl, Clemmons $D R, 1995$, Insulin-like growth factors and their binding proteins: biological actions, Endocrine Reviews, 16, 3-34.

21. Jorritsma R, 2003, Negative energy balance in dairy cows as related to fertility, Dissertation, Utrecht University.

22. Kaneko JJ, 1989, Clinical Biochemistry of Domestic Animals, Academic Press

23. Kalaitzakis E, Roubies N, Panousis N, Pourliotis K, Kaldrymidou E, Karatzias H, 2007. Clinicopathological evaluation of hepatic lipidosis in periparturient dairy cattle, $J$ Vet Intern Med, $21,835-45$.

24. Kida $K, 2002$, The metabolic profile test: Its practicability in assesing feeding management and periparturient diseases in high yielding commercial dairy herds, J Vet Med Sci, 64, 7, 557-63.

25. Kovačević $B, 2004$, Hormonal and metabolic status of high-milking dairy cows during peripartal period, $\mathrm{PhD}$ thesis, University of Belgrade.

26. Kovačević $M, 2000$, Liver function and hormonal status in different condition dairy cows during pregnancy and early lactation, $\mathrm{PhD}$ thesis, University of Belgrade.

27. Kunz PL, Blum JW, Hart IC, Bicket H, Landis J, 1985, Effect of different energy intake before and after calving on food intake performance and blood hormones and metabolites in dairy cows, Anim Prod, 219-31.

28. McGuire MA, Dwyer DA, Bauman DE, Smith DF, 1998, Insulin-like growth factors in plasma and afferent mammary lymph of lactating cows deprived of feed or treated with bovine somatotropin, J Dairy Sci, 81, 4, 950-7.

29. Narongsak Chaiyabutr, Siripen Komolovanich, Suwanakiet Sawangkoon, Sumpun Preuksagorn, Somchai Chanpongsang, 1998, Glucose metabolism in vivo in crossbred Holstein Cattle 
feeding different types of roughage during late pregnancy and early lactation, Comparative Biochemistry and Physiology.

30. Nixon DA, Akasha MA, Anderson RR, 1988, Free and total thyroid hormones in serum of Holstein cows, J Dairy Sci, 71, 5, 1152-60.

31. Nikolić JA, Šamanc H, Begović J, Damnjanović Z, Đoković R, Kostić G, Krsmanović J, Resanović V, 1997, Low peripheral serum thyroid hormone status independently affects the hormone profile of the healthy and ketotic cows during the first week post partum, Acta Vet (Beograd), 47, 1, 314.

32. Nikolić JA, Šamanc $H$, Kovačević M, Bugarski D, Masnikosa R, 2001, Serum concentrations of insulin like growth factors and thyroid hormones in healthy and ketotic dairy cows during the puerperium, Acta Vet (Beograd), 51, 2-3, 73-88.

33. Pethes D, Bokori J, Rudas P, Frenyo VL, Fekete S, 1985, Thyroxine, triiodothyronine, reversetriiodothyronine and other physiological characteristics of periparturient cows fed restricted energy, J Dairy Sci, 68, 1148-54.

34. Radojičić B, 1995, Influence of propionate on level cortisol, insulin, glucose and lipids in the blood of cattle. PhD thesis, University of Belgrade.

35. Radojičić B, Djuričić B, Matarugić D, Kasagić D, 2007, Importance of haematology-biochemical analyses in differential diagnostic of dairy cattle. II Congress of Veterinarians of Republic of Srpska, 24-27 october, 2007, Banjaluka ,Veterinary Journal of Republic of Srpska, VII, No 2, p128-33.

36. Rehage J, Mertens M, Stuckhofe-Zurwieden N, 1996. Post surgical convalescence of dairy cows with left abomasal displacement in relation to fatty liver, J Schweizer Archiv Tierheilbunde, 138, 361-8.

37. Reist M, Erdin D, von Euw D, Tschuemperlin K, Leunberger H, Chillard Y et al., 2002, Estimation of energy balance at the individual and heard level using blood and milk trits in high-yelding dairy cows, J Dairy Sci, 85, 3314-27.

38. Scharma BK, Vandehar MJ, Ames NK, 1994, Expression of insulin-like growth factor-I in cows at different stages of lactation and in late lactation cows treated with somatotropin, J Dairy Sci, 77, 2232-41.

38. Stojić V, Gvozdić D, Kirovski D, Nikolić JA, Huszenicza Gy, Šamanc H, Ivanov I, 2001, Serum thyroxine and triiodothyronine concentrations prior to and after delivery in primiparous Holstein cows, Acta Vet (Beograd), 51, 1, 3-8.

39. Šamanc H, Radojičić B, Kovačević $M$, Đoković $R$, 2004, Some endocrine-metabolic parameters in the blood serum of healthy and ketotic cows. Boock Abstract, 12, Congress of Mediterranean Federation of Healthy and Production of Ruminants, Istanbul, Turkey.

40. Tiirats $T$, 1997, Thyroxine, triiodothyronine and reverse-triiodothyronine concentrations in blood plasma in relation to lactation stage, milk yield, energy and dietary protein intake in Estonian dairy cows, Acta Vet Scand, 38, 4, 339-48.

41. Vicini JL, Buonomo FC, Veenhuizen JJ, Miller MA, Clemmons DR, Collier RJ, 1991, Nutrient balance and stage of lactation affect responses of insulin, insulin-like growth factors-I and II, and insulinlike growth factor-binding protein 2 to somatotropin administration in dairy cows, J Nutr, 121, 1656-64.

42. Wathes DC, Bourne N, Cheng Z, Mann GE, Taylor VJ, Coffey MP, 2007, Multiple Correlation Analyses of Metabolic and Endocrine Profiles with Fertility in Primiparous and Multiparous Cows. J Dairy Sci, 90, 1310-25.

43. Wylie ARG, Woods S, Carson AF, McCoy M, 2008, Periprandial Changes in Metabolite and Metabolic Hormone Concentrations in High-Genetic-Merit Dairy Heifers and Their Relationship to Energy Balance in Early Lactation. J Dairy Sci, 91, 577-86. 
Acta Veterinaria (Beograd), Vol. 61, No. 5-6, 555-565, 2011.

\title{
ENDOKRINI I METABOLIČKI PROFIL JUNICA HOLŠTAJNA I CRVENOG HOLŠTAJNA U PERIPARTALNOM PERIODU
}

\author{
KASAGIĆ D, RADOJIČIĆ BILJANA, GVOZDIĆ D, MIRILOVIĆ M i MATARUGIĆ D
}

\section{SADRŽAJ}

Cilj ovih istraživanja je bio određivanje koncentracije triijodtironina $\left(\mathrm{T}_{3}\right)$, tiroksina $\left(\mathrm{T}_{4}\right)$, insulinu sličnog faktora rasta-I (IGF-I) i biomarkera, pokazatelja funkcionalnog stanja jetre u krvnom serumu dva varijeteta junica Holštajn rase u peripartalnom periodu. Prvu eksperimentalnu grupu (I) činile su junice crno belog holštajna $(n=10)$, a drugu grupu (II) junice crvenog holštajna $(n=10)$. Krv za analize je uzimana iz repne vene, tri puta u peripartalnom periodu ( 5 dana pre partusa, na dan partusa i do 5 dana posle partusa), a krvni serum je odvajan nakon spontane koagulacije. U krvnom serumu je radioimunološkom metodom (RIA, INEPZemun) određivanja koncentracija trijodtironina $\left(T_{3}\right)$, tiroksina $\left(T_{4}\right)$ i insulinu sličnog faktora rasta-I (IGF-I). Koncentracija glukoze (G), ukupnih proteina (TP), albumina, (Alb), ureje, ukupnog bilirubina (tBil) i aktivnost aspartat aminotrasferaze (AST) je određivana upotrebom komercijalnih ELISA kitova. Statistička značajnost razlika srednjih vrednosti ispitivanih endokrinih i metaboličkih parametara je određena Studentovim t-testom.

Dobijeni rezultati ukazuju na vrlo različite koncentracije hormona štitne žlezde u krvnom serumu junica oba varijeteta holštajna pre i posle partusa. Koncentracija $T_{3}$ je bila statistički značajno niža u grupi II nakon partusa, a $T_{4}$ značajno viša pre partusa $(p<0.05)$ u odnosu na nivo hormona u grupi I. Za prosečne vrednosti koncentracija IGF-I, između isptivanih grupa nije ustanovljena statistički značajna razlike ni u jednom od tri perioda ispitivanja. Utvrđena je srednje pozitivna korelacija između koncentracije $T_{3}$ i $T_{4}(r=0,74)$ u krvnom serumu junica grupe I, i vrlo visoka pozitivna korelacija u grupi II $(r=0,81)$. Koncentracija TP, Alb i ureje bila je statistički značajno viša kod junica grupe I u sva tri perioda ispitivanja. Nivo tBil u krvnom serumu je takođe bio povišen kod junica grupe I u sva tri perioda ispitivanja, ali su statistički značajne razlike između srednjih vrednosti ustanovljene samo u periodu nakon partusa. Aktivnost AST u krvnom serumu junica oba varijeteta značajno je varirala u svim periodima ispitivanja i nisu ustanovljene statistički značajne razlike između srednjih vrednosti. 